\title{
The usefulness of the sum of rotation parameter in scoliosis screening
}

\author{
J Chowańska ${ }^{1,2^{*}}$, T Kotwicki ${ }^{2}$ \\ From 8th International Conference on Conservative Management of Spinal Deformities and SOSORT 2011 \\ Annual Meeting \\ Barcelona, Spain. 19-21 May 2011
}

\section{Purpose of the study}

It was to assess the usefulness of the Sum of Rotation parameter in scoliosis screening.

\section{Background}

The Sum of Rotation parameter (SR) represents the sum of absolute values of angles of trunk rotation (ATRs) measured with a scoliometer on three spinal levels: proximal thoracic, main thoracic and thoracolumbar/lumbar. This parameter is useful in following-up the patient during conservative scoliosis management, because it documents the global rotational trunk deformity [1-4].

\section{Materials and methods}

In a cohort of 996 school girls, aged $11.0 \pm 1.0$ years, range 9 to13, the average, standard deviation, minimum and maximum values of SR were calculated separately for three distinct subgroups: (a) ATR: $0^{\circ}-3^{\circ}$, (b) ATR $4^{\circ}$ to $6^{\circ}$ and (c) ATR $\geq 7^{\circ}$.

\section{Results}

The SR value was: (a) $0.9 \pm 1.2$, range $0.0^{\circ}$ to $6.0^{\circ}, \mathrm{N}=870$, (b) $5.5 \pm 1.9$, range $4.0^{\circ}$ to $17^{\circ}, \mathrm{N}=94$, (c) $10.2 \pm 3.3$, range $7.0^{\circ}$ to $20.0^{\circ}, \mathrm{N}=32$. Normal children with important $S R$ values were identified $\left(S R=2^{\circ}+2^{\circ}+2^{\circ}=6^{\circ}\right)$.

\section{Conclusions}

The use of SR parameter seems not reveal additional information in scoliosis screening comparing to simple ATR measurement. Moreover, a risk of bias is present if the cut-off criterion of $7^{\circ}$ is applied.

\footnotetext{
'Rehasport Clinic, Poznań, Poland; Spine Disorders Unit, Department of Pediatric Orthopedics and Traumatology, University of Medical Sciences, ul. Poznan, Poland

Full list of author information is available at the end of the article
}

\author{
Author details \\ ${ }^{1}$ Rehasport Clinic, Poznań, Poland; Spine Disorders Unit, Department of \\ Pediatric Orthopedics and Traumatology, University of Medical Sciences, ul. \\ Poznan, Poland. ${ }^{2}$ Spine Disorders Unit, Department of Pediatric Orthopedics \\ and Traumatology, University of Medical Sciences, Poznan, Poland.
}

Published: 27 January 2012

\section{References}

1. Bunnell WP: Outcome of spinal screening. Spine 1993, 18:1572-1580.

2. Goldberg CJ, Kaliszer M, Moore DP, Fogarty EE, Dowling FE: Surface topography, Cobb angles and cosmetic change in scoliosis. Spine (Phila Pa 1976) 2001, 26:E55-E63.

3. Kotwicki T, Kinel E, Chowańska J, Bodnar-Nanuś A: POTSI, Hump Sum and Sum of Rotation - new surface topography parameters for evaluation of scoliosis deformity of the trunk. Fizjoterapia Polska 2008, 8:231-240.

4. Suzuki N, Inami K, Ono T, Kohno K, Asher MA: Analysis of posterior trunk symmetry index (POTSI) in Scoliosis. Part 1. In Research into Spinal Deformities 2. Amsterdam, IOS Press;Stokes, I.A.F 1999:81-84.

doi:10.1186/1748-7161-7-S1-O59

Cite this article as: Chowańska and Kotwicki: The usefulness of the sum of rotation parameter in scoliosis screening. Scoliosis 2012 7(Suppl 1): 059.
Submit your next manuscript to BioMed Central and take full advantage of:

- Convenient online submission

- Thorough peer review

- No space constraints or color figure charges

- Immediate publication on acceptance

- Inclusion in PubMed, CAS, Scopus and Google Scholar

- Research which is freely available for redistribution

Submit your manuscript at www.biomedcentral.com/submit
C Biomed Central

\section{Biomed Central}

